\title{
Biological roles of NAC transcription factors in the regulation of biotic and abiotic stress responses in solanaceous crops
}

\author{
Solomon Tweneboah - Sang-Keun Oh
}

Received: 6 February 2017 / Revised: 19 March 2017 / Accepted: 20 March 2017

(c) Korean Society for Plant Biotechnology

\begin{abstract}
Evolutionary studies conducted on NAC (NAM, ATAF1\&2, and CUC2) genes for all major groups of land plants, indicate the presence of the NAC subfamilies, even in the early land plants. The varied roles played by NAC proteins in plant growth and development range from the formation of shoot apical meristem, floral organ development, reproduction, lateral shoot development, and defense responses to biotic and abiotic stresses. Considering the value and importance of solanaceous crops, the study of NAC proteins in these plants needs to be intensified. This will help to identify and functionally characterize their promoters, which will subsequently aid in engineering plants with improved performance under stressful conditions. In this review, the functionally characterized NAC transcription factors specific to tomato, potato, tobacco, chili pepper and eggplant (aubergine) are summarized, clearly indicating their biological functions in the defense mechanism of the plants, against biotic and abiotic stresses.
\end{abstract}

Keywords NAC transcription factors, Solanaceous crops, Biotic and abiotic stresses

\section{Introduction}

Living things encounter lots of biotic and abiotic stresses in their environment which impact negatively on their growth, development and functioning. When animals encounter such stresses in one environment they easily migrate to new environments where conditions are more conducive for their continued survival and functioning. Plants, on the contrary, are sessile; thus, they are not able to move away from suboptimal conditions in their environment. Plants need to

Solomon Tweneboah · Sang-Keun Oh $(\varangle)$

(Department of Applied Biology, College of Agriculture \& Life Sciences, Chungnam National University, Daejeon, 34134, Republic of Korea)

e-mail: sangkeun@cnu.ac.kr endure all the effects of harsh environmental and biotic stresses they are faced with. To prevent extinction of their species, plants have evolved a network of robust and densely interconnected systems for rapid signal perception, reaction and adaptation to suboptimal environmental conditions (Smékalová et al. 2013). In these physiological and biochemical network systems, plants utilize a number of hormones, secondary messengers, and enzymes which activate various genes to confer stress tolerance to the plants. Among the numerous stress tolerance and defense response genes in the body of plants are the families of transcription factors. Transcription factors are grouped into many different classes based on the domains that bind to specific DNA sequences in the regulatory regions of downstream target genes (Kikuchi et al. 2000). The role of transcription factors in activating and suppressing gene expression is largely modulated through gene promoters and their associated cis-acting elements (Zou et al. 2011; Hernandez-Garcia and Finer 2014). The gene promoters containing multiple cisacting elements are located upstream of the gene coding regions; the cis-acting elements serving as specific binding sites for proteins involved in transcription initiation and regulation (Hernandez-Garcia and Finer 2014). Contained in the promoter region, near the transcription initiation site, are the core promoter and the promoter-proximal cis-acting sequences (Griffiths et al. 2000). TATA-box and cis-elements contained in the core promoter are, respectively, the binding sites for TATA-box-Binding Protein (TFIID TBP) - a transcription initiation factor, and RNA polymerase II the basic transcriptional machinery (Griffiths et al. 2000; Hernandez-Garcia and Finer 2014). The promoter-proximal cis-acting sequences bind to proteins that in turn assist in the binding of RNA polymerase II to its promoter (Griffiths et al. 2000). At a considerable distance - about $50 \mathrm{~kb}$ upstream or downstream from the promoter that they control, are the distal cis-acting sequence containing enhancers and silencers. Enhancers are regulatory sequences that increase 
the rate of transcription while silencers reduce the rate of transcription (Griffiths et al. 2000).

In plants, transcription factors regulate their target genes through binding to the cis-acting elements located on the promoters or interacting with other transcription factors thereby inducing or repressing the related gene expression (Ma et al. 2010; 2013). Basically, plant transcription factors are critical regulatory factors in modulating the temporal and spatial expression of the genes involved in defense response (Liu et al. 2014). Among plant transcription factors are the families of AP2/EREBP (APETALA2/EthyleneResponsive Element Binding Protein), bZIP (Basic Leucine Zipper), zinc finger, NAC (NAM, ATAF1\&2, CUC2), MYB (myeloblastosis) (Ulm et al. 2004; Hirota et al. 2007), and WRKY (Rushton et al. 2010). Among these, plant-specific NAC transcription factors constitute one of the largest families of transcription factors in plants (Nuruzzaman et al. 2013; Li et al. 2016) and they are known for their roles in many plant growth and developmental processes as well as abiotic and abiotic stress responses (Nakashima et al. 2012).

NAC gene expression responses are largely related to their promoters and every NAC gene contains at least one cis-element type in their promoter sequences ( $\mathrm{Lv}$ et al. 2016). In their study to identify putative stress-responsive ciselements in the promoter regions of Brachypodium distachyon NAC $(B d N A C)$ genes, $1 \mathrm{~kb}$ upstream promoter sequences of the $B d N A C$ genes were examined by You et al. (2015) using PlantCARE database search. In this examination, You et al. (2015) found $101 B d N A C$ genes that contained at least one cis-element related to stress or hormone response, with 44 of them having more than 5 cis-elements, giving the indication that $B d N A C$ genes might be involved in the stress-response or hormones-response processes. Additionally, 135 ABA-responsive elements (ABREs), 107 MeJA-responsiveness elements (CGTCA-motifs), 99 MYB binding sites, 64 TCA-elements (SA-responsiveness) and 51 TC-rich repeats were detected in the promoters of $B d N A C$ genes, suggesting that $B d N A C$ genes have important roles in the responses to $\mathrm{ABA}, \mathrm{MeJA}$, drought, $\mathrm{SA}$ and defense responses (You et al. 2015).

Many other recent reports demonstrate that NAC proteins often act as regulators in various stress signaling pathways which may include both biotic and abiotic stimuli in plants (Olsen et al. 2005; Kleinow et al. 2009; Puranik et al. 2012). Effects on plant defense responses under both biotic and abiotic stresses have significantly shown the importance of overexpression or knockdown of specific $N A C$ genes in crops such as tomato, potato, tobacco, chili pepper and eggplant (aubergine). Therefore, in this review we summarize the recent reports on characterized NAC transcription factors specific to solanaceous crops, clearly showing their functions as defense regulators against various biotic and abiotic stresses.

\section{NAC transcription factors in plants}

The NAC transcription factor family is divided into several subfamilies such as the NAM, ATAF, and OsNAC3 (Kikuchi et al. 2000). The name NAC is originally derived from the names of three proteins containing similar DNA-binding domains, and these proteins are Petunia NAM, Arabidopsis ATAF1\&2, and CUC2 (Aida et al. 1997). NAM (no apical meristem) proteins are plant development proteins responsible for shoot apical meristem development (Souer et al. 1996; Sablowski and Meyerowitz, 1998). ATAF1 and ATAF2 (Arabidopsis transcription activation factor 1\&2) genes have the ability to activate the CaMV $35 \mathrm{~S}$ promoter in yeast (Souer et al. 1996; Kikuchi et al. 2000; Duval et al. 2002). Overexpression of ATAF1 and ATAF2 respectively regulates drought tolerance (Wu et al. 2009), and negatively regulates resistance to $F$. oxysporum and also represses pathogenesisrelated proteins (Delessert et al. 2005). CUC2 (cup-shaped cotyledon 2) is an essential gene for shoot meristem initiation as well as the formation and stable positioning of carpel margin meristems (Liu et al. 2014).

The proteins of the NAC gene family contain a highly conserved N-terminal DNA-binding domain and a variable C-terminal domain (Olsen et al. 2005, Fang et al. 2008) (Fig. 1). The N-terminal region, which is involved in DNA binding and formation of homodimers or heterodimers with other NAC domain proteins (Olsen et al. 2005; Cenci et al. 2014), consists of approximately 150-160 amino acids with five subdomains A-E (Olsen et al. 2005; Nuruzzaman et al. 2013). Each subdomain is distinguishable by blocks of heterogeneous amino acids or gaps (Kikuchi et al. 2000). Subdomains C and D, rich in basic amino acids, contain putative nuclear localization signals (Kikuchi et al. 2000; Duval et al. 2002). Subdomains D and E contain a 60 amino acid region where the DNA-binding domain is located (Duval et al. 2002). The C-terminal region, which is highly diversified in length and sequence (He et al. 2005), is implicated in transcriptional activation or repression activity (Puranik et al. 2012; Ma et al. 2013; Cenci et al. 2014). Nuruzzaman et al. (2013) explained that the C-terminal region is large and possesses protein-binding activity.

According to Zhu et al. (2012), evolutionary studies conducted on NAC genes for all major groups of land 

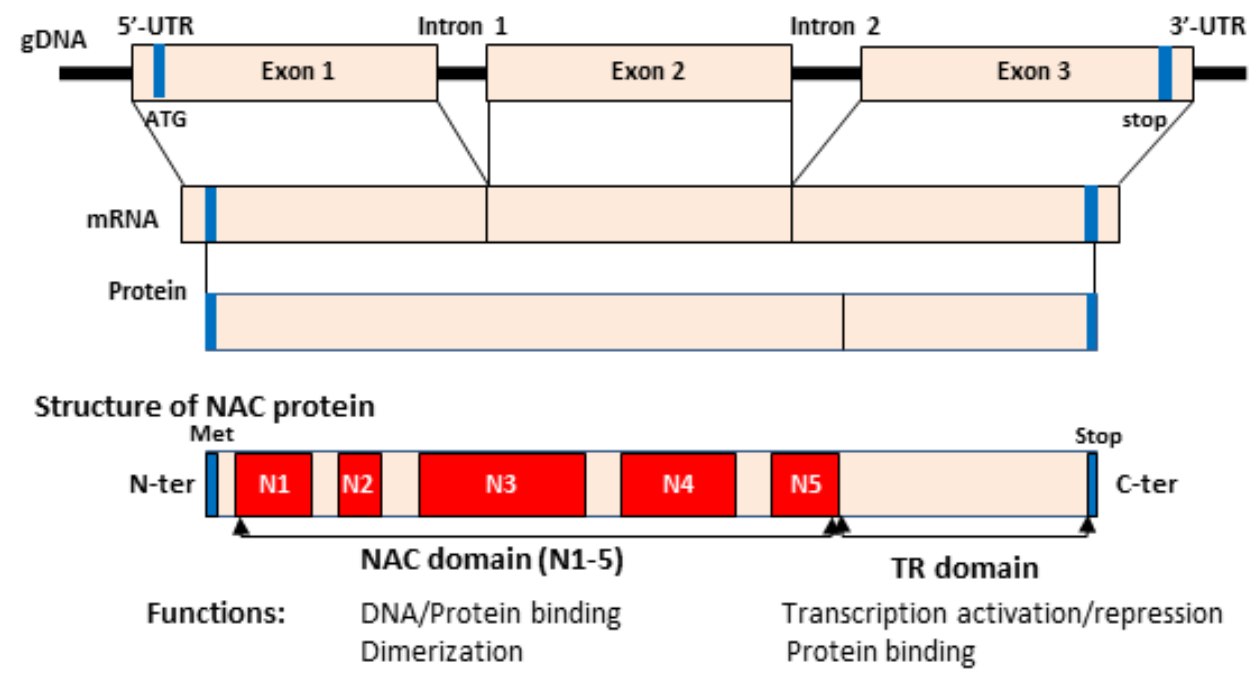

Fig. 1 Structure of NAC transcription factors. Schematic representation showing a typical NAC transcription factors (ATAF1) with highly conserved amino acid residue (NAC domain) at the N-terminal, which is further divided into five conserved homologous motifs, N1-N5 (shown in red boxes), and the transcription activating C-terminal region (Puranik et al. 2012)

plants, have shown that some NAC subfamilies were already present in early divergent land plants. Whole genome analyses of the NAC gene family, performed in several plant species indicate that the number of NAC family members at the genomic level varies from species to species; ranging from 30 in the early divergent land plants to 167 in Musa acuminate (Cenci et al. 2014). The availability of these complete plant genomic sequences has led to the identification of 117 NAC genes in Arabidopsis thaliana, 151 in Oryza sativa, 79 in Vitis vinifera, 101 in tomato, 109 in potato, 106 pepper (Fig. 3, reviewed by Kim et al. 2014), 26 in Citrus, 163 in Populus trichocarpa, and 152 each in Glycine max and Nicotiana (Rushton et al. 2008; Hu et al. 2010; Le et al. 2011; Kim et al. 2014; Nuruzzaman et al. 2015).

The expression levels of NAC genes occurring differently in specific plant tissues in the presence of different stimuli suggest that NAC transcription factors not only play crucial and diverse roles during growth and development (Zhu et al. 2014c) but they, also, are involved in defense responses to abiotic and biotic stresses (Fujita et al. 2004; Wang et al. 2009; Hu et al. 2010). Zhao et al. (2015) reported that wheat (Triticum aestivum) NAC1-type transcription factor (TaNAC-S) suppresses leaf senescence and promotes grain yield and protein content in wheat. In rice, OsNAC6, RIMI, OsNAC4, ONAC122 and ONAC131 genes regulated disease resistance against $M$ oryzae, Rice dwarf virus, and hypersensitive cell death (Nakashima et al. 2007; Kaneda et al. 2009; Motoyasu et al. 2009; Yoshii et al. 2009; 2010; Sun et al. 2013). Being the first plant to have its entire genome sequenced, Arabidopsis is considered a model plant system for plant biology research, and many of its NAC genes have been functionally characterized. The Arabidopsis ANAC019, ANAC055, ANAC072, ANAC096, ANAC2, ATAF1, and ATAF2 have been shown to play important roles in the plant's tolerance against drought and salinity stresses (He et al. 2005; Lu et al. 2007; Wu et al. 2009; Xu et al. 2013). However, there are reports that indicate that Arabidopsis NAC proteins ATAF1, ATAF2, ANAC019, AAC042, ANAC055, ANAC072, CBNAC1 and NTL6 are negative regulators of defense responses against pathogens such as Botrytis cinerea, Alternaria brassicicola, Fusarium oxysporum and Pseudomonas syringae pv. tomato (Bu et al. 2008; Wang et al. 2009; Seo et al. 2010; Saga et al. 2012; Zheng et al. 2012; Liu et al. 2014).

Roles of NAC transcription factors in solanaceous crops

Members of the solanaceae form one of the most agronomically important groups of flowering plants. The family is very diverse with over 3,000 species (Rushton et al. 2008; Kim et al. 2014) occurring in more than 90 genera (Knapp, 2002). Plants belonging to the solanaceae are adapted to a wide range of geo-ecological habitats ranging from the driest deserts to tropical rainforests (Kim et al. 2014). Humans have depended on solanaceous crops such as tomato (Solanum lycopersicum), chili pepper (Copsicum anmum), potato (Solamm tuberosum), and aubergine (Solanum melongena) for food and for their medicinal benefits. Tobacco (Nicotiana tabacum), another solanaceae species, is an important model plant for biological research since its whole genome is sequenced. Phylogenetic relationship analysis performed by Rushton et al. (2008) on tobacco revealed NAC subfamily genes, 
A

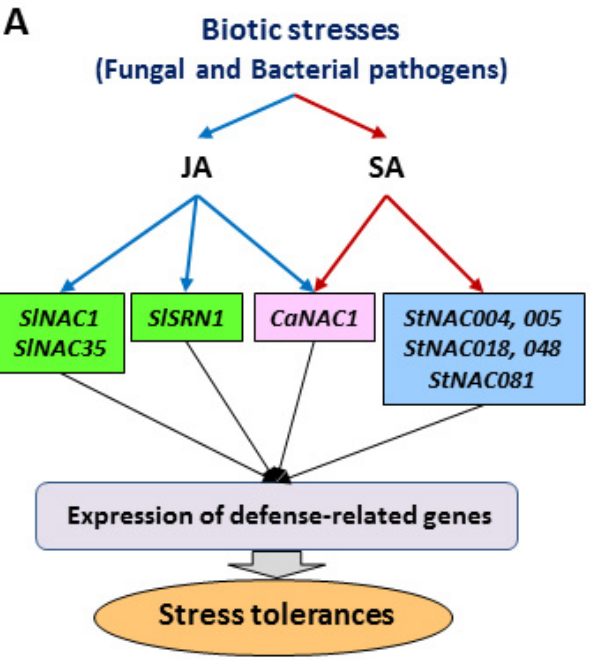

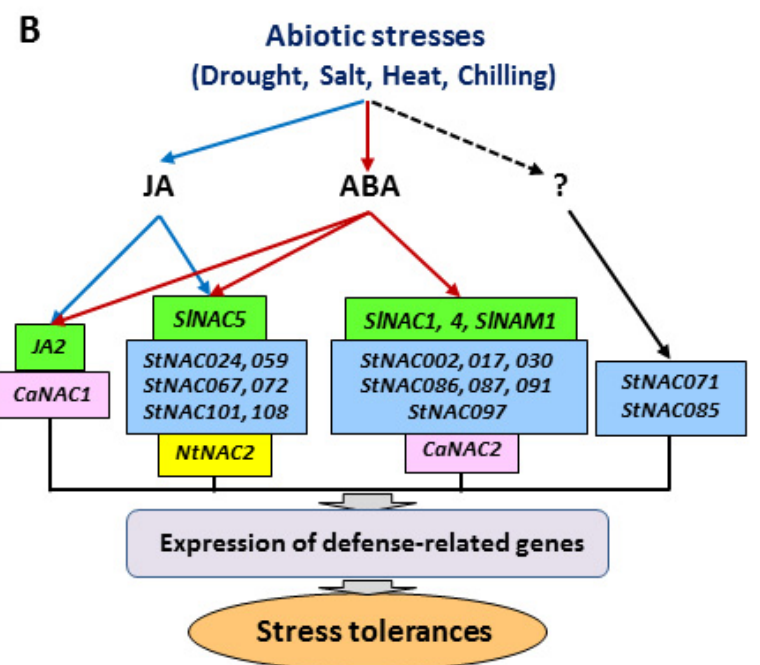

Fig. 2 A model showing the role of specific NAC transcription factors in defense responses during biotic and abiotic stress conditions. (A) During pathogen attack, NAC transcription factors SINAC1, SINAC35, SmNAC, SISRN1, StNAC004, 005, 018, 048, 081, and CaNAC1 elicit plant defenses through SA or JA (and their cross-talk) signaling pathways. (B) Under abiotic stress conditions, a large number of NAC transcription factors activate the expression of defense-related genes through the JA or ABA signaling pathways. Color keys: tomato (green); pepper (pink); potato (blue); and tobacco (yellow)

termed TNAC genes, which are unique to Solanaceae species. Specific NAC transcription factors have been implicated in the formation of shoot apical meristem, floral organ development, reproduction, lateral shoot development, defense against insect pests and pathogens, regulation of programmed cell death, abiotic stress responses, and responses to hormones (Olsen et al. 2005; Rushton et al. 2008; Hu et al. 2010). Essentially, NAC transcription factors are central components of several plant innate immune systems, basal defense, as well as systemic acquired resistance (Nuruzzaman et al. 2013).

A large set of defense-related genes are activated by NAC genes to elicit multiple immune responses when plants encounter stresses (Nakashima et al. 2012). Under biotic stresses, at least three signaling mediators, specifically, salicylic acid (SA), jasmonic acid (JA) and ethylene are generally harmonized to generate plant defenses (Glazebrook, 2001; Oh et al. 2005), and NAC transcription factors such as SINAC1, SINAC35, SmNAC, SISRN1, StNAC004, 005, 018, 048, 081, and CaNAC1 are involved in complex network of signaling pathways to induce local and systemic disease resistance (Fig. 2A). JA is also induced to mediate responses under certain abiotic stresses such as drought and salinity while abscisic acid (ABA) mediates most responses under abiotic stresses (Fig. 2B) (Nakashima et al. 2012).

Roles of NAC transcription factors in tomato (Solanum lycopersicum)
About 101 NAC transcription factors are found in the tomato plant as seen in the Plant Transcription Factor Database (Jin et al. 2014). In the characterization and expression analysis of tomato genes, Song et al. (2015) identified 10 TNAC genes which were expressed in tomato under various forms of abiotic stresses (Table 1). Solanum lycopersicum NAC1 (SINAC1), an ATAF subfamily transcription factor, abundantly expresses in the nuclei of root, flower, green fruit as well as seed cells to confer salt stress tolerance to tomato plants during salt stress (Yang et al. 2011). SINAC1 is also accumulated during chilling stress $\left(4^{\circ} \mathrm{C}\right)$, heat stress $\left(40^{\circ} \mathrm{C}\right)$, osmotic stress and mechanical wounding aiding the plant's tolerance against these stresses (Ma et al. 2013; Liang et al. 2015; Meng et al. 2016). Although Pseudomonas syringae pv. tomato (Pst) DC3000 has evolved mechanisms to suppress PAMP-triggered basal defense, the induction of SlNACl was not repressed by Pst DC3000 resulting in more protein production, triggering protection against $P_{s t}$ DC3000 (Huang et al. 2013). In their work, Ma et al. (2013) induced the expression of SINAC1 in tomato plants through the application of abscisic acid (ABA), methyl jasmonate (MeJA), salicylic acid (SA), gibberellin $\left(\mathrm{GA}_{3}\right)$, ethylene, methyl viologen and hydrogen peroxide $\left(\mathrm{H}_{2} \mathrm{O}_{2}\right)$. Ripening fruits overexpressing SINAC1 displayed yellow/orange color instead of red pigmentation and this was coupled with reduced fruit firmness due to the accumulation of $\mathrm{ABA}$ (Ma et al. 2014). Infection of tomato by tomato leaf curl virus (TLCV) also induced SINAC1 expression, however, SINACl overexpression corresponded with increased TLCV 
Table 1 Functionally characterized NAC transcription factors in tomato

\begin{tabular}{|c|c|c|c|c|}
\hline Genes & Sub-family & Stress inducing transcription & Methods & References \\
\hline \multirow{4}{*}{ SINAC1* } & \multirow{4}{*}{ ATAF } & Salt stress & Salt stress tolerance & Yang et al. (2011) \\
\hline & & $\begin{array}{l}\text { Tomato leaf curl virus (TLCV) } \\
\text { infection }\end{array}$ & Increased TLCV replication & Selth et al. (2005) \\
\hline & & $\begin{array}{l}\text { Chilling stress }\left(4^{\circ} \mathrm{C}\right) \text {, Heat stress } \\
\left(40^{\circ} \mathrm{C}\right) \text {, Osmotic stress, } \\
\text { Mechanical wounding, Application } \\
\text { of } \mathrm{ABA}, \mathrm{MeJ}, \mathrm{SA}, \mathrm{GA}_{3} \text {, } \\
\text { ethylene, methyl viologen and } \\
\mathrm{H}_{2} \mathrm{O}_{2}\end{array}$ & $\begin{array}{l}\text { Chilling stress tolerance, } \\
\text { Heat stress tolerance, } \\
\text { Fruit ripening, } \\
\text { Altered fruit pigmentation and } \\
\text { early fruit softening }\end{array}$ & $\begin{array}{l}\text { Ma et al. (2013); Liang et al. } \\
\text { (2015); Meng et al. (2016); } \\
\text { Ma et al. (2014) }\end{array}$ \\
\hline & & Pseudomonas infection & $\begin{array}{l}\text { Defense against Pseudomonas } \\
\text { infection }\end{array}$ & Huang et al. (2013) \\
\hline SINAM1 & NAM & $\begin{array}{l}\text { Chilling stress }\left(4^{\circ} \mathrm{C}\right) \text {, Treatment of } \\
\text { PEG, } \mathrm{NaCl}, \mathrm{ABA}, \mathrm{MeJA}\end{array}$ & $\begin{array}{l}\text { Chilling stress tolerance in tomato, } \\
\text { increased germination rate and } \\
\text { higher photosynthetic rate under } \\
\text { chilling stress in tobacco }\end{array}$ & $\begin{array}{l}\text { Yang et al. (2011); } \\
\mathrm{Li} \text { et al. (2016) }\end{array}$ \\
\hline SISRN1 & NAM & $\begin{array}{l}B \text { cinerea or Pst DC } 3000 \\
\text { infection, SA, Jasmonic acid (JA), } \\
1 \text {-amino } \\
\text { cyclopropane-1-carboxylic acid, } \\
\text { Drought stress }\end{array}$ & $\begin{array}{l}\text { Defense against } B \text {. cinerea and Pst } \\
\text { DC } 3000\end{array}$ & Liu et al. (2014) \\
\hline SINAC4 & NAM & $\begin{array}{l}\text { Mechanical wounding, Treatment } \\
\text { of } \mathrm{NaCl} \text { and MeJA, Dehydration, } \\
\text { Low temperature }\left(4^{\circ} \mathrm{C}\right)\end{array}$ & $\begin{array}{l}\text { Salt and drought tolerance, Fruit } \\
\text { ripening and carotenoid } \\
\text { accumulation }\end{array}$ & Zhu et al. $(2014 b, 2014 c)$ \\
\hline SINAC3 & NAM & $\begin{array}{l}\text { Suppressed by salt stress, drought } \\
\text { stress and ABA treatment }\end{array}$ & $\begin{array}{l}\text { Young embryo and endosperm } \\
\text { development }\end{array}$ & Han et al. $(2012 ; 2014)$ \\
\hline $\begin{array}{l}\text { S } 1 \text { NAC } 5- \\
\text { SINAC10 }\end{array}$ & & $\begin{array}{l}\mathrm{NaCl} \text { stress, wounding, dehydration, } \\
\text { and high/low temperature. All } \\
\text { except SINAC6 are induced by } \\
\text { ABA, ACC, GA } 3 \text {, MeJA, and } \\
\mathrm{IAA}^{* *}\end{array}$ & $\begin{array}{l}\text { SINAC5 improves } \mathrm{NaCl} \text { stress } \\
\text { tolerance }\end{array}$ & Zhu et al. (2014a) \\
\hline SINAC35 & & $\begin{array}{l}\text { Drought stress, Salt stress, } \\
\text { Bacterial pathogen }\end{array}$ & $\begin{array}{l}\text { Root growth and development, } \\
\text { Resistance to bacterial pathogen }\end{array}$ & Wang et al. (2016) \\
\hline JA2 & & $\mathrm{ABA}$ & Stomatal closure & Du et al. (2014) \\
\hline JA2L & & JA and coronatine & Stomatal reopening & Du et al. (2014) \\
\hline
\end{tabular}

* SINAC; Solanum lycopersicum NAC, ** ACC; 1-aminocyclopropane-1-carboxylic acid, GA 3 ; Gibberellic acid, IAA; Indole-3-acetic acid

replication (Selth et al. 2005).

SINAM1, SISRN1, SINAC3\&4 belong to the NAM subfamily. SINAM1, mostly induced by chilling stress $\left(4^{\circ} \mathrm{C}\right)$, treatment of polyethylene glycol $(\mathrm{PEG})$, salt $(\mathrm{NaCl})$, $\mathrm{ABA}$ and MeJA, confers chilling stress tolerance to both growing tomato plants as well as germinating seeds (Yang et al. 2011; Li et al. 2016). SISRN1 transcription factor defends the plant against Botrytis cinerea and Pst DC3000 infection (Liu et al. 2014). SINAC3 and SINAC4 encourage embryo development and enhance salt and drought stress tolerance respectively (Han et al. 2012; 2014; Zhu et al. 2014b, 2014c). SINAC5-10 range of transcription factors improve salt stress tolerance of tomato plants (Zhu et al. 2014a). SINAC35 not only encourages root growth and development but also enhances resistance against bacterial pathogens (Wang et al. 2016). According to Du et al. (2014)
JA2 and JA2L transcription factors regulate the opening and closure of stomata preventing excessive plant water loss during water stress conditions.

Roles of NAC transcription factors in potato (Solanum tuberosum)

Genome-wide analysis conducted by Singh et al. (2013) identified $110 \mathrm{NAC}$ genes in potato encoding for 136 proteins, including 36 putative TNAC proteins. The potato NAC genes were designated as StNAC followed by numbers 1110 based on the position of their corresponding genes on chromosomes $1-12$ and from top to bottom. NAM domain was present in all the StNAC proteins except for StNAC034, which contained additional tyrosine kinase domain (PF07714) (Singh et al. 2013). The biology of potato NAC genes is 
Table 2 Functionally characterized NAC transcription factors in potato

\begin{tabular}{|c|c|c|c|c|}
\hline Genes & Sub-family & Stress inducing transcription & Methods & References \\
\hline StNAC017, 030, 086, 097 & NAM & $\begin{array}{l}\text { Salt and heat stresses, mannitol } \\
\text { treatment }\end{array}$ & $\begin{array}{l}\text { Salt and heat stress } \\
\text { tolerance }\end{array}$ & Singh et al. (2013) \\
\hline StNAC002, 025, 087, 091 & NAM & $\begin{array}{l}P . \text { infestans infection, wounding, salt } \\
\text { stress, drought stress, salicylic acid, } \\
\text { ABA }\end{array}$ & $\begin{array}{l}\text { Salt and drought } \\
\text { tolerance }\end{array}$ & $\begin{array}{l}\mathrm{Zu} \text { et al. (2014); } \\
\text { Singh et al. (2013) }\end{array}$ \\
\hline StNAC073 & NAM & nd & nd & Singh et al. (2013) \\
\hline StNAC082 & $"$ & nd & nd & Singh et al. (2013) \\
\hline StNAC024, 059, 067, 072, 108, 101 & $"$ & $\mathrm{NaCl}$ stress & Salt stress tolerance & Singh et al. (2013) \\
\hline StNAC053, 072, 080, 101 & $"$ & Manitol treatment & nd & Singh et al. (2013) \\
\hline StNAC071, 085 & $"$ & Heat stress & Heat stress tolerance & Singh et al. (2013) \\
\hline StNAC072, 101 & $"$ & ABA & $\mathrm{Nd}$ & Singh et al. (2013) \\
\hline StNAC004, $005,018,048,081$ & $"$ & P. infestans infection & $\begin{array}{l}\text { Resistance to } \\
P \text {. infestans infection }\end{array}$ & $\begin{array}{l}\text { Collinge and } \\
\text { Boller }(2001)\end{array}$ \\
\hline StNAC004, 051 & $"$ & Mechanical wounding & nd & $\begin{array}{l}\text { Collinge and } \\
\text { Boller }(2001)\end{array}$ \\
\hline StNAC017, 072, 090, 097, 101, 110 & $"$ & BABA treatment $* * *$ & nd & Singh et al. (2013) \\
\hline StNAC007, 090, 094 & $"$ & BTH treatment $* * * *$ & $"$ & Singh et al. (2013) \\
\hline StNAC005, 090, & $"$ & IAA treatment & $"$ & Singh et al. (2013) \\
\hline StNAC016, 059, 090, & $"$ & BAP and GA3 treatments & $"$ & Singh et al. (2013) \\
\hline StNAC090 & $"$ & ABA treatment & $"$ & Singh et al. (2013) \\
\hline StNAC034*, 075 & $"$ & nd & $"$ & \\
\hline
\end{tabular}

poorly understood but informative reports have been published recently. According to $\mathrm{Zu}$ et al. (2014) and Singh et al. (2013) StNAC002, 025, 087 and 091 confer salt and drought tolerance to potato plant, and they are induced by mechanical wounding, salt stress, drought stress, application of salicylic acid ABA, and Phytophthora infestans infection (Table 2). Similarly, StNAC024, 059, 067, 108, 072, 101 enhance salt stress tolerance (Singh et al. 2013). Collinge and Boller (2001) also indicate that StNAC004, 005, 018, 048,051, 081 improves potato plant's ability to resist $P$. infestans infection.

Roles of NAC transcription factors in tobacco (Nicotiana tabacum)

Tobacco is one of the most studied higher plant species. Out of the 2500 transcription factors analyzed in tobacco, Rushton et al. (2008) found 203 complete or partial NAC domains and a minimum number of 152 NAC genes. They also identified seven major NAC gene subfamilies, six of which were present in tobacco as well as in other plant species (like rice, Arabidopsis, etc.), and a seventh subfamily which contained 50 tobacco NAC (TNAC) genes accounting for approximately one quarter of all NAC genes in tobacco. The TNAC genes were further subdivided into three major clades - A, B, and $\mathrm{C}$, with members in each clade having clearly different primary amino acid sequences in their NAC domains. Tobacco NtNAC84, NtNAC176 and NtNAC156 genes belonged to clade $\mathrm{A}, \mathrm{B}$ and $\mathrm{C}$ respectively while potato CV505554, tomato BI422367, and pepper U204177 genes belonged to TNAC clade C. Besides lacking LPPG and YPNG motifs that are conserved in NAC family members, TNAC genes contain D/ExE motifs instead of the conserved D/EEE motif found in NACs (Rushton et al. 2008; Singh et al. 2013).

Nicotiana tabacum NAC (NtNAC) transcription factors range from $\mathrm{NtNAC1}$ to over NtNAC176, but not much published information is available on their functional characterization. Available information indicates that NtNAC-R1, which is induced by mechanical wounding during topping, increases lateral root development and nicotine content $(\mathrm{Fu}$ et al. 2013) while NtNAC2 confers salinity stress tolerance to the tobacco plants (Han et al. 2015) (Table 3). 
Table 3 Functionally characterized NAC transcription factors in tobacco, chili pepper and aubergine

\begin{tabular}{|c|c|c|c|c|c|}
\hline Plants & Genes & Sub-family & Stress inducing transcription & Methods & References \\
\hline \multirow[t]{5}{*}{ Tobacco } & $N t N A C-R 1^{*}$ & nd & $\begin{array}{l}\text { Mechanical wounding during } \\
\text { topping }\end{array}$ & $\begin{array}{l}\text { Increased number of lateral roots } \\
\text { and nicotine contents }\end{array}$ & Fu et al. (2013) \\
\hline & NtNAC2 & nd & High level salt stress & Salinity stress tolerance & Han et al. (2015) \\
\hline & NtNAC151 & nd & nd & nd & Rushton et al. (2008) \\
\hline & NtNAC156 & $"$ & nd & nd & Rushton et al. (2008) \\
\hline & NtNAC176 & $"$ & nd & nd & Rushton et al. (2008) \\
\hline \multirow[t]{2}{*}{ Chili pepper } & CaNAC1** & NAM & $\begin{array}{l}\text { A non-host pathogen } \\
\text { Xanthomonas axonopodis pv. } \\
\text { glycines infection, salicylic } \\
\text { acid, ethephon treatment }\end{array}$ & $\begin{array}{l}\text { Defense responses resulting in } \\
\text { hypersensitive sensitive cell death, } \\
\text { Drought stress and BAX tolerance in } \\
\text { CaNAC1 transgenic tobacco plants } \\
\text { (on-going work) }\end{array}$ & Oh et al. (2005) \\
\hline & CaNAC2 & NAC2 & $\begin{array}{l}\text { Cold stress, salt stress and } \\
\text { ABA treatment }\end{array}$ & $\begin{array}{l}\text { Cold stress tolerance, root growth } \\
\text { and seed maturation }\end{array}$ & Guo et al. (2015) \\
\hline Eggplant & $S m N A C^{* * *}$ & NAC & $\begin{array}{l}\text { Ralstonia solanacearum } \\
\text { infection, MeJA treatment }\end{array}$ & $\begin{array}{l}\text { Increased susceptibility of plant to } \\
\text { bacterial wilt }\end{array}$ & $\mathrm{Na}$ et al. (2016) \\
\hline
\end{tabular}

*NtNAC; Nicotiana tabacum NAC, **CaNAC;Capsicum annuum NAC, ***SmNAC; Solanum melonge

Roles of NAC transcription factors in chili pepper (Capsicum annuum)

In a recent work on chili pepper genome sequencing, Kim et al. (2014) identified a total of 2,139 genes which were unique to solanaceous plants, with 756 of them being unique to chili pepper. They further explained that pepper genome shared 27 gene families with Arabidopsis, 51 with grape and 20 with rice. Also, they found 2,153 transcription factors ( $6.25 \%$ of total genes) and transcriptional regulators in 80 gene families in chili pepper, some of which are involved in disease resistance and cellular functions (e.g. cytochrome P450), and 70 heat shock proteins that were significantly expanded in the pepper genome. In total, 105 putative Capsicum annuum NAC (CaNAC) transcription factors in pepper genome were identified and CaNAC proteins contain the typical NAC domain at the N-terminus including NLS localization, and highly divergent motif at the C-terminus. The predicted pepper NAC transcription factors with higher similarity for sequence and structure as compared to known NAC-proteins were retrieved from the various plants genomes (Fig. 3). Kim et al (2014) indicated that the size of the pepper NAC gene family is slightly expanded compared to the tomato genome. Moreover, they found a Solanaceae-specific NAC subgroup in pepper, tomato, and potato genome. This subgroup contains 33 members in pepper, 25 in tomato, and 35 in potato genome, whereas representatives of Arabidopsis- and rice-specific NAC subgroup were found in the Arabidopsis and rice genomes (Fig. 3; Kim et al. 2014).

CaNAC1 transcription factor was first discovered and characterized by $\mathrm{Oh}$ et al. (2005). This gene enhanced defense response against non-host pathogens resulting in hypersensitive cell death. According to Oh et al. (2005) the cross-talk between SA and JA signaling pathways might account for the regulation of defense responses by CaNAC1 transcription factor. In an on-going experiment on $\mathrm{CaNACl}$ transgenic Nicotiana tabacum plants, overexpression of CaNACl resulted in a higher tolerance of transgenic plants to pathogen infection and drought stress than the wild type (data not shown).

A report on aubergine (Solamum melongena) NAC (SmNAC) transcription factor expression by $\mathrm{Na}$ et al. (2016) indicates that SmNAC is induced by Ralstonia solanacearum infection and MeJA treatment, and SmNAC overexpression resulted in the reduced accumulation of SA which increased bacterial wilt susceptibility of aubergine. Published information on the functional characterization of chili pepper and aubergine NAC transcription factors are so scanty (Oh et al. 2005; Guo et al. 2015) and more study in this area need to be conducted.

\section{Conclusion}

A crop's ability to respond appropriately to biotic and abiotic stresses may ultimately increase its chances of survival and may also affect its yields positively. As global food demand continues to increase in the face of climate change, paying more attention to the study of NAC transcription factors in solanaceous plant to identify and functionally characterize their promoters will help to 


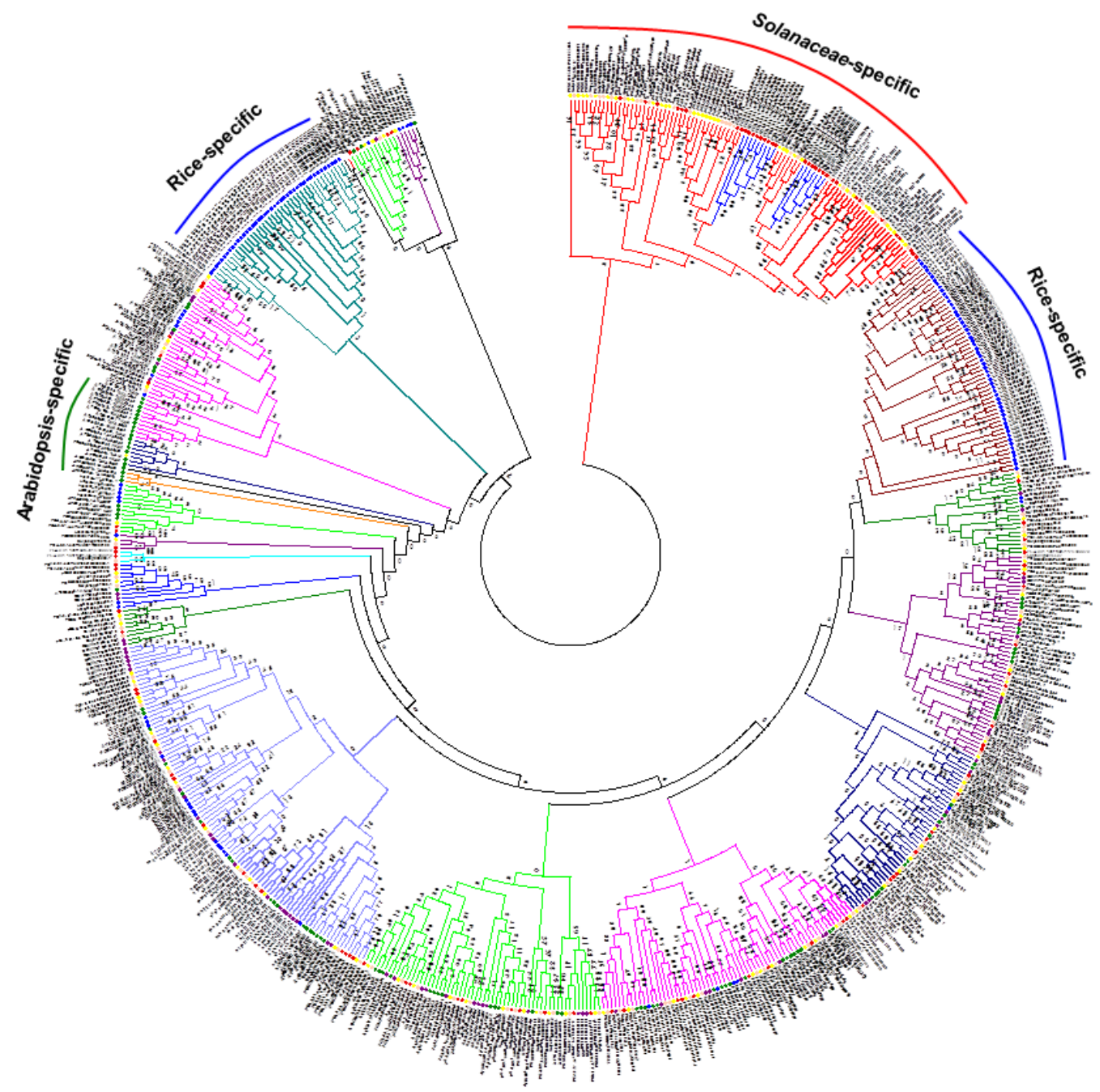

Fig. 3 Phylogenic tree between tomato, potato and pepper, grape, rice, and Arabidopsis NAC genes. The deduced full-length amino acid sequences of 101 tomato (Solyc), 109 potato (PGSC), 106 pepper (PGA), 71 grape (GSVIVT), 140 rice (LOC_Os), and 113 Arabidopsis NAC genes, were aligned by Clustal W. The evolutionary relationship was inferred with the MEGA 5 program (Tamura et al. 2011) using the Neighbor-Joining method with 500 bootstrap replicates (Modified from Kim et al. 2014). Each NAC subgroup is indicated in a specific color circle. Tomato (pale pink), potato (yellow), pepper (red), grape (brown), rice (blue), and Arabidopsis (green)

engineer crops with improved performance under stressful conditions. A lot of transcription factors in solanaceae are characterized yet several TNAC transcription factors remain unknown (Rushton et al. 2008). Considering the involvement of NAC transcription factors in plant growth, development and defense, further experimental investigation into NAC transcription factors is indispensable.

\section{Acknowledgement}

This work was supported by research fund of Chungnam National University.

\section{References}

Aida M, Ishida T, Fukaki H, Fujisawa H, Tasaka M (1997) Genes involved in organ separation in Arabidopsis: an analysis of the cup-shaped cotyledon mutant. Plant Cell 9:841-857

Bu Q, Jiang H, Li CB, Zhai Q, Zhang J, Wu X, Sun J, Xie Q, Li C (2008) Role of the Arabidopsis thaliana NAC transcription factors ANAC019 and ANAC055 in regulating jasmonic acid-signaled defense responses. Cell Res 18:756-767

Cenci A, Guignon V, Roux N, Rouard M (2014) Genomic analysis of NAC transcription factors in banana (Musa acuminata) and definition of NAC orthologous groups for monocots and dicots. Plant Mol Biol 85:63-80

Collinge M, Boller T (2001) Differential induction of two potato genes, Stprx2 and StNAC, in response to infection by 
Phytophthora infestans and to wounding. Plant Mol Biol 46:521-529

Delessert C, Kazan K, Wilson IW, Straeten DVD, Manners J, Dennis ES, Dolferus R (2005) The transcription factor ATAF2 represses the expression of pathogenesis-related genes in Arabidopsis. Plant J 43:745-757

Du M, Zhi Q, Deng L, Li S, Li H, Yan L, Huang Z, Wang B, Jiang H, Huang T, Li CB, Wei J, Kang L, Li J, Li C (2014) Closely related NAC transcription factors of tomato differentially regulate stomatal closure and reopening during pathogen attack. Plant Cell 26:3167-3184

Duval M, Hsieh TF, Kim SY, Thomas TL (2002) Molecular characterization of AtNAM: a member of the Arabidopsis NAC domain superfamily. Plant Molecular Biology 50:237-248

Fang Y, You J, Xie K, Xie W, Xiong L (2008) Systematic sequence analysis and identification of tissue-specific or stress-responsive genes of NAC transcription factor family in rice. Mol Genet Genomics 280:547-563

Fu Y, Guo H, Cheng Z, Wang R, Li G, Huo G, Liu W (2013) NtNAC-R1, a novel NAC transcription factor gene in tobacco roots, responds to mechanical damage of shoot meristem. Plant Physiol Biochem 69:74-81

Fujita M, Fujita Y, Maruyama K, Seki M, Hiratsu K, Ohme-Takagi M, Tran LS, Yamaguchi-Shinozaki K, Shinozaki K (2004) A dehydration-induced NAC protein, RD26, is involved in a novel ABA-dependent stress-signaling pathway. Plant J. 39: 863-876

Glazebrook J (2001) Genes controlling expression of defense responses in Arabidopsis-2001 status. Curr Opin Plant Biol 4:301-308

Griffiths AJF, Wessler SR, Lewontin RC, Gelbart WM, Suzuki DT, Miller JH (2005) An Introduction to Genetic Analysis (8th edition). New York: New York: WH Freeman; Basingstoke: Palgrave. pp 301-339

Guo WL, Wang SB, Chen RG, Chen BH, Du XH, Yin YX, Gong $\mathrm{ZH}$, Zhang YY (2015) Characterization and expression profile of $C a N A C 2$ pepper gene. Front Plant Sci 6:755

Han Q, Zhang J, Li H, Luo Z, Ziaf K, Ouyang B, Wang T, Ye Z (2012) Identification and expression pattern of one stressresponsive NAC gene from Solanum lycopersicum. Mol Biol Rep. 39:1713-1720

Han QQ, Qiao P, Song YZ, Zhang JY (2015) Structural analysis and tissue-specific expression patterns of a novel salt-inducible NAC transcription factor gene from_Nicotiana tabacum_cv. Xanthi. J Hortl Sci Biotechnol 89:700-706

Han QQ, Song YZ, Zhang JY, Liu L F (2014)_Studies on the role of the SINAC3_gene in regulating seed development in tomato (Solanum lycopersicum). J Hortl Sci Biotechnol 89:423-429

He XJ, Mu RL, Cao WH, Zhang ZG, Zhang JS, Chen SY (2005) AtNAC2, a transcription factor downstream of ethylene and auxin signaling pathways, is involved in salt stress response and lateral root development. Plant J 44:903-916

Hernandez-Garcia CM and Finer JJ (2014) Identification and validation of promoters and cis-acting regulatory elements. Plant Science 217-218:109-119
Hirota A, Kato T, Fukaki H, Aida M, Tasaka M (2007) The auxin-regulated AP2/EREBP gene PUCHI is required for morphogenesis in the early lateral root primordium of Arabidopsis. Plant Cell 19:2156-2168

Hu R, Qi G, Kong Y, Kong D, Gao Q, Zhou G (2010) Comprehensive analysis of NAC domain transcription factor gene family in Populus trichocarpa. BMC Plant Biology 10:145

Jin JP, Zhang H, Kong L, Gao G, Luo JC (2014) PlantTFDB 3.0: a portal for the functional and evolutionary study of plant transcription factors. Nucleic Acids Res 42:D1182-D1187

Kaneda T, Taga Y, Takai R, Iwano M, Matsui H, Takayama S, Isogai A, Che FS (2009) The transcription factor OsNAC4 is a key positive regulator of plant hypersensitive cell death

Kikuchi K, Ueguchi-Tanaka M, Yoshida KT, Nagato Y, Matsusoka M, Hirano HY (2000) Molecular analysis of the NAC gene family in rice. Mol Gen Genet 262:1047-1051

Kim S, Park M, Yeom SI, Kim YM, Lee JM, Lee HA, Seo E, Choi J, Cheong K, Kim KT, Jung K, Lee GW, Oh SK, Bae C, Kim SB, Lee HY, Kim SY, Kim MS, Kang BC et al (2014) Genome sequence of the hot pepper provides insights into the evolution of pungency in Capsicum species. Nature Genetics 46:270-280

Kleinow T, Himbert S, Krenz B, Jeske H, Koncz C (2009) NAC domain transcription factor ATAF1 interacts with SNF1-related kinases and silencing of its subfamily causes severe developmental defects in Arabidopsis. Plant Science 177:360-370

Knapp S (2002) Tobacco to tomatoes: a phylogenetic perspective on fruit diversity in the Solanaceae. J Exp Botany 53: 2001-2022

Le DT, Nishiyama R, Watanabe Y, Mochida K, YamaguchiShinozaki K, Shinozaki K (2011) Genome-wide survey and expression analysis of the plant-specific NAC transcription factor family in soybean during development and dehydration stress. DNA Res 18:263-276

Li XD, Zhuang KY, Liu ZM, Yang DY, MaNN, Meng QW (2016) Overexpression of a novel NAC-type tomato transcription factor, SINAM1, enhances the chilling stress tolerance of transgenic tobacco. J Plant Physiol 204:54-65

Liang XQ, Ma NN, Wang GD, Meng X, Ai XZ, Meng QW (2015) Suppression of SlNACl reduces heat resistance in tomato plants. Biol Plant 59:92-98

Liu B, Ouyang Z, Zhang Y, Li X, Hong Y, Huang L, Liu S, Zhang H, Li D, Song F (2014) Tomato NAC transcription factor SISRN1 positively regulates defense response against biotic stress but negatively regulates abiotic stress response. PLoS ONE 9: e102067

Lu PL, Chen NZ, An R, Su Z, Qi BS, Ren F, Chen J, Wang XC (2007) A novel drought-inducible gene, ATAF1, encodes a NAC family protein that negatively regulates the expression of stress-responsive genes in Arabidopsis. Plant Mol Biol 63:289-305

Lv X, Lan S, Guy KM, Yang J, Zhang M, Hu Z (2016) Global Expressions Landscape of NAC Transcription Factor Family and Their Responses to Abiotic Stresses in Citrullus lanatus. Scientific Reports 6:30574 
Ma NN, Zuo YQ, Liang XQ, Yin B, Wang GD, Meng QW (2013) The multiple stress-responsive transcription factor SINAC1 improves the chilling tolerance of tomato. Physiologia Plantarum 149:474-486

Ma HL, Zhou HL, Zhang HY, Zhao J (2010) Cloning and expression analysis of an AP2/ERF gene and its responses to phytohormones and abiotic stresses in rice. Rice Sci 17:1-9

Ma N, Feng H, Meng X, Li D, Yang D, Wu C, Meng Q (2014) Overexpression of tomato SINAC1 transcription factor alters fruit pigmentation and softening. BMC Plant Biol 14:351

Matsusoka M, Hirano HY (2000) Molecular analysis of the NAC gene family in rice. Mol Gen Genet 262:1047-1051

Meng C, Yang D, Ma X, Zhao W, Liang X, Ma N, Meng Q (2016) Suppression of tomato SINAC1 transcription factor delays fruit ripening. J Plant Physiol 193:88-96

$\mathrm{Na} \mathrm{C}$, Shuanghua W, Jinglong F, Bihao C, Jianjun L, Changming C, Jin J (2016) Overexpression of the eggplant (Solamum melongena) NAC family transcription factor S $m N A C$ suppresses resistance to bacterial wilt. Scientific Reports 6:31568

Nakashima K, Takasaki H, Mizoi J, Shinozaki K, Yamaguchi-Shinozaki K (2012) NAC transcription factors in plant abiotic stress responses. BBA 1819:97-103

Nakashima K, Tran LP, Nguyen DV, Fujita M, Maruyama K, Todaka D, Ito Y, Hayashi N, Shinozaki K, Yamaguchi-Shinozaki K (2007) Functional analysis of a NAC-type transcription factor OsNAC6 involved in abiotic and biotic stress-responsive gene expression in rice. Plant J 51:617-630

Nuruzzaman M, Sharoni AM, Kikuchi S (2013) Roles of NAC transcription factors in the regulation of biotic and abiotic stress responses in plants. Front Microbiol 4:248

Nuruzzaman M, Sharoni AM, Satoh K, Karim MR, Harikrishna JA, Shimizu T, Sasaya T, Omura T, Haque MA, Hasan SMZ, Ahmad A, Kikuchi S (2015) NAC transcription factor family genes are differentially expressed in rice during infections with Rice dwarf virus, Rice black-streaked dwarf virus, Rice grassy stunt virus, Rice ragged stunt virus, and Rice transitory yellowing virus. Front Plant Sci 6:676

Oh SK, Lee S, Yu SH, Choi D (2005) Expression of a novel NAC domain-containing transcription factor (CaNAC1) is preferentially associated with incompatible interactions between chili pepper and pathogens. Planta 222:876-887

Olmstead RG, Bohs L, Migid HA, Santiago-Valentin E, Garcia VF, Collier SM (2008) A molecular phylogeny of the Solanaceae. Taxon 57:1159-1181

Olsen AN, Erns, HA, Leggio LL, Skriver K (2005) NAC transcription factors: structurally distinct, functionally diverse. Trends Plant Sci 10:1360-1385

Portis E, Barchi L, Toppino L, Lanteri S, Acciarri N, Felicioni N, Fusari F, Barbierato V, Cericola F, Valè G, Rotino GL (2014) QTL mapping in eggplant reveals clusters of yield-related loci and orthology with the tomato genome. PLoS ONE 9:e89499

Puranik S, Sahu PP, Srivastava PS, Prasad M (2012). NAC proteins: regulation and role in stress tolerance. Trends Plant Sci 17:369-381

Rushton PJ, Bokowiec MT, Han S, Zhang HH, Brannock JF, Chen
X, Laudeman TW, Timko MP (2008) Tobacco transcription factors: novel insights into transcriptional regulation in the solanaceae. Plant Physiol 147:280-295

Rushton PJ, Somssich IE, Ringler P, Shen QJ (2010) WRKY transcription factors. Trends Plant Sci. 15:247-258

Sablowski RW, Meyerowitz EM (1998) A homolog of no apical meristem is an immediate target of the floral homeotic genes APETALA3/ PISTILLATA. Cell 92:93-103

Saga H, Ogawa T, Kai K, Suzuki H, Ogata Y, Sakurai N, Shibata D, Ohta D (2012) Identification and characterization of ANAC042, a transcription factor family gene involved in the regulation of camalexin biosynthesis in Arabidopsis. Mol Plant Microbe Interact 25:684-696

Särkinen T, Bohs L, Olmstead RG, Knapp S (2013) A phylogenetic framework for evolutionary study of the nightshades (Solanaceae): a dated 1000-tip tree. BMC Evol Biol 13:214

Selth LA, Dogra SC, Rasheed MS, Healy H, Randles JW, Rezaian MA (2005) A NAC domain protein interacts with tomato leaf curl virus replication accessory protein and enhances viral replication. Plant Cell 17:311-325

Seo PJ, Kim MJ, Park JY, Kim SY, Jeon J, Lee YH, Kim J, Park CM (2010) Cold activation of a plasma membrane-tethered NAC transcription factor induces a pathogen resistance response in Arabidopsis. Plant J 61:661-671

Singh AK, Sharma V, Pal AK, Acharya V, Ahuja PS (2013) Genome-wide organization and expression profiling of the NAC transcription factor family in potato (Solanum tuberosum L.). DNA Res 20:403-423

Smékalová V, Doskočilová A, Komis G, Šamaj J (2013) Crosstalk between secondary messengers, hormones and MAPK modules during abiotic stress signalling in plants. Biotechnol Advances 32:2-11

Song FY, Su HY, Cheng XH, Zhu LY, Wang L (2015) Characterization and expression analysis of TNAC genes of tomato. Bull Bot Res 35:898-903

Souer E, van Houwelingen A, Kloos D, Mol J, Koes R (1996) The no apical meristem gene of Petunia is required for pattern formation in embryos and flowers and is expressed at meristem and primordia boundaries. Cell 85:159-170

Stern S, de Fatima Agra M, Boh, L (2011) Molecular delimitation of clades within New World species of "spiny solanums" (Solanum subg. Leptostemonum) Taxon 60:1429-1441

Sun L, Zhang H, L, D, Huang L, Hong Y, Ding XS, Nelson RS, Zhou X, Song F (2013) Functions of rice NAC transcriptional factors, ONAC122 and ONAC131, in defense responses against Magnaporthe grisea. Plant Mol Biol 81:41-56

Tamura K, Peterson D, Peterson N, Stecher G, Nei M, Kumar S (2011) MEGA5: molecular evolutionary genetics analysis using maximum likelihood, evolutionary distance, and maximum parsimony methods. Mol Biol Evol 28:2731-2739

Ulm R, Baumann A, Oravecz A, Mate Z, Adam E, Oakeley EJ, Schafer E, Nagy F (2004) Genome-wide analysis of gene expression reveals function of the bZIP transcription factor HY5 in the UV-B response of Arabidopsis. Proc Natl Acad Sci USA 101:1397-1402 
Wang G, Zhang S, Ma X, Wang Y, Kong F, Meng Q (2016) A stress-associated NAC transcription factor (SINAC35) from tomato plays a positive role in biotic and abiotic stresses. Physiologia Plantarum 158:45-64

Wang X, Basnayake BM, Zhang H, Li G, Li W, Virk N, Mengiste T, Song F (2009) The Arabidopsis ATAF1, a NAC transcription factor, is a negative regulator of defense responses against necrotrophic fungal and bacterial pathogens. Mol Plant-Microbe Interact 22:1227-1238

Weese TL, Bohs L (2007) A three-gene phylogeny of the genus Solanum (Solanaceae) Syst Bot 32:445-463

Weizao Huang W, Miao M, Joanna Kud J, Niu X, Ouyang B, Zhang J, Ye Z, Kuhl JC, Yongsheng Liu Y, Xiao F (2013) SINAC1, a stress-related transcription factor, is fine-tuned on both the transcriptional and the post-translational level. New Phytologist 197:1214-1224

Wu Y, Deng Z, Lai J, Zhang Y, Yang C, Yin B, Zhao Q, Zhang L, Li Y, Yang C, Xie Q (2009) Dual function of Arabidopsis ATAF1 in abiotic and biotic stress responses. Cell Res 19:1279-1290

Xu Q, He Q, Li S, Tian Z (2014) Molecular characterization of StNAC2 in potato and its overexpression confers drought and salt tolerance. Acta Physiol Plant 36:1841

Xu ZY, Kim SY, Hyeon DY, Kim DH, Dong T, Park Y, Jin JB, Joo SH, Kim SK, Hong JC, Hwang D, Hwang I (2013). The Arabidopsis NAC transcription factor ANAC096 cooperates with bZIP-type transcription factors in dehydration and osmotic stress responses. Plant Cell 254708-4724

Yang R, Deng C, Ouyang B, Ye Z (2011) Molecular analysis of two salt-responsive NAC-family genes and their expression analysis in tomato. Mol Biol Rep 38:857-863

Yoshii M, Shimizu T, Yamazaki M, Higashi T, Miyao A, Hirochika $\mathrm{H}$, Omura $\mathrm{T}$ (2009) Disruption of a novel gene for a NAC-domain protein in rice confers resistance to Rice dwarf virus. Plant J 57:615-625

Yoshii M, Yamazaki M, Rakwal R, Kishi-Kaboshi M, Miyao A, Hirochika H (2010) The NAC transcription factor RIM1 of rice is a new regulator of jasmonate signaling. Plant $\mathrm{J} 61$ : 804-815

You J, Zhang L, Song B, Qi X, Chan Z (2015) Systematic Analysis and Identification of Stress-Responsive Genes of the NAC Gene Family in Brachypodium distachyon. PLos ONE 10: e0122027

Zhao D, Derkx AP, Liu DC, Buchner P, Hawkesford MJ (2015) Overexpression of a NAC transcription factor delays leaf senescence and increases grain nitrogen concentration in wheat. Plant Biol (Stuttg). 17:904-913

Zheng XY, Spivey NW, Zeng W, Liu PP, Fu ZQ, Klessig DF, He SY, Dong X (2012) Coronatine promotes Pseudomonas syringae virulence in plants by activating a signaling cascade that inhibits salicylic acid accumulation. Cell Host Microbe. 11:587-596

Zhu M, Hu Z, Zhou S, Wang L, Dong T, Pan Y, Chen G (2014a) Molecular Characterization of Six Tissue-Specific or StressInducible Genes of NAC Transcription Factor Family in Tomato (Solanum lycopersicum). J Plant Growth Regulation 33:730-744

Zhu M, Chen G, Zhang J, Zhang Y, Xie Q, Zhao Z, Pan Y, Hu Z (2014b) The abiotic stress-responsive NAC-type transcription factor SINAC4 regulates salt and drought tolerance and stress-related genes in tomato (Solanum lycopersicum). Plant Cell Rep. 33:1851-1863

Zhu M, Chen G, Zhou S, Tu Y, Wang Y, Dong T, Hu Z (2014c) A new tomato NAC (NAM/ATAF1/2/CUC2) transcription factor, SINAC4, functions as a positive regulator of fruit ripening and carotenoid accumulation. Plant Cell Physiol. 55:119-135

Zhu T, Nevo E, Sun D, Peng J (2012) Phylogenetic analyses unravel the evolutionary history of NAC proteins in plants. Evolution 66:1833-1848

Zou C, Sun K, Mackaluso JD, Seddon AE, Jin R, Thomashow MF, Shiu SH (2011) Cis-regulatory code of stress-responsive transcription in Arabidopsis thaliana. Proc. Nat. Acad. Sci. USA 108:14992-14997 